Tarih Kültür ve Sanat Araştırmaları Dergisi

Revue des Recherches en Histoire Culture et Art مجلة البحوث التاريخية والثقافية والفنية
Vol. 6, No. 1, February 2017

Copyright (C) Karabuk University

http://kutaksam.karabuk.edu.tr

\title{
DOI: 10.7596/taksad.v6i1.773
}

Citation: Bostani, M., Shojaifar, M., Riki, J., Shahbakhsh, A., \& Hashemzehi, S. (2017). Assessment of Social Capital in terms of Participation, Knowledge, Trust, and Social Cohesion: Zahedan Case Study. Journal of History Culture and Art Research, 6(1), 720-736. doi:http://dx.doi.org/10.7596/taksad.v6i1.773

\section{Assessment of Social Capital in terms of Participation, Knowledge, Trust, and Social Cohesion: Zahedan Case Study}

\author{
Maryam Karimian Bostani* ${ }^{1}$, Mohammad Reza Shojaifar ${ }^{2}$, Javad Riki ${ }^{3}$, \\ Alireza Shahbakhsh ${ }^{4}$, Soudabeh Hashemzehi ${ }^{5}$
}

\begin{abstract}
It is anticipated that the urban population in developing countries increases more than double from 2000 to 2030. This rapid population transformation to cities will be difficult. Therefore, the municipal administration will be involved in numerous challenges in cities. For this purpose, social capital as a bottom-up planning is one of the appropriate ways of management and dealing with these challenges. The aim of this study was to measure the social capital in four aspects of knowledge, participation, social cohesion, and trust in Zahedan. The research method of this research is descriptive-analytic in an applied type. Library studies and surveying (questionnaire) were used to collect the required data. The questions in this survey were designed based on four indicators of social capital. The statistical population of the present study is 575,116 people residing in Zahedan in 2011. One sample T- test was used for calculations. The results of the analysis show that the social capital criteria in the city of Zahedan are undesirable in all four criteria.
\end{abstract}

Keywords: Social capital, Knowledge, Trust, Participation, Social cohesion, Zahedan.

\footnotetext{
${ }^{1}$ Corresponding Author, Assistant Professor in the Department of Geography, Zahehan Branch, Islamic Azad University, Zahedan, Iran.

${ }^{2}$ Ph.D.Student of Geography and Urban Planning. Department of Geography, Zahehan Branch, Islamic Azad University, Zahedan, Iran.

${ }^{3}$ Ph.D.Student of Geography and Urban Planning. Department of Geography, Zahehan Branch, Islamic Azad University, Zahedan, Iran.

${ }^{4}$ Ph.D.Student of Geography and Urban Planning. Department of Geography, Zahehan Branch, Islamic Azad University, Zahedan, Iran.

${ }^{5}$ Ph.D.Student of Geography and Urban Planning. Department of Geography, Zahehan Branch, Islamic Azad University, Zahedan, Iran.
} 


\section{Introduction}

The rapid growth of urbanization along with major changes in the urban lifestyle influenced by the capitalist system and the introduction of automobiles and other new technologies have led to emergence of numerous problems of urbanization and urban development in social, economic, environmental, and especially, physical aspects of cities (Latifi, Azimi, 2010). The massive scale of urbanization and urbanism naturally would face with problems such as urban poverty, massive migrations and the lack of services, lack of infrastructure, pollution and congestion for cities, which is considered as the major challenges for urban management and the economic, social, and cultural process of cities (PourMohammadi, Hosseinzadeh, Piri, 2011). Coincident with these problems, the cities have faced to new challenges that need for reflection and change in relations with the public and the environment along with the rapid process of population growth and demand for resources and services (Alizadeh et al., 2015: 106). Mainly positions towards urban developments from the traditional view are in a rational manner with government-oriented management, which considers these reflections and change of attitude as a crisis (Destatte, 2010: 86). However, due to problems in cities and inventory management system and the necessity to face and solve them in participation, the dominant management theory i.e. sufficient authority for the government has been compromised since the 1980s that two key factors were influential in this process. The impact of neo-liberal economic thought, which advocates reducing the role of government as much as possible and the emergence of civil society and social movements that demand political participation and democratic form of state (MehdiZadeh, 2006). Today, the participation approach is considered as a part of civil society and democratic planning in both as a basis for decisionmaking and as a method to achieve common cooperation and activities in the process of improving individual and collective life. One of the most important effects in the planning and management process is creating interest and trust in people to develop, strengthen social cohesion and cooperation and empathy, efficient use of public and private resources and reduce centralization (Mahdizadeh, 2006: 316). Given the changes in urban development and management and paying more attention to sustainable urban management approach, a development has been created whose basis is attention to decentralization approach in the organization. Sustainability is one of the issues, which is emphasized in recent years in various countries, especially in urban communities. In the direction of sustainability, social capital plays a very important role, so that sustainable development has determined its role in the social environment such as social capital with regard to concepts such as social justice, comprehensive development, and social welfare. Many studies have shown the unsustainable consequences in the current trend of global development. In the meantime, citizens have a 
decisive share in the creation of the consequences (Firouz Abadi, 2005). Therefore, the necessity of citizen participation can be felt in the planning and management.

As the center of Sistan and Baluchestan Province Zahedan has become a city with a high rate of immigration with its geographical unique position in recent decades due to immigration from other cities of the province on the one hand and locating near the border on the other hand. Like all cities of the Third World and other Iranian cities, this city has structural and functional problems, including the growth of false jobs, marginalization, begging, and so on. As noted above, some of the components that could be associated with these issues are knowledge, trust, citizenship participation, and social cohesion, i.e. social capital. Defect or deficiency in these affairs can arguably make problems in the development of the city. Already, many problems in the metropolis of Zahedan are visible. Now the main research question with respect to the subject matter in the study is that how is the knowledge, trust, citizenship participation, and social cohesion in Zahedan.

\section{Literature}

Several internal and external studies have been carried out on social capital in recent years. The following can be noted. One of the studies is about trust, which is one of the main indicators of social capital that consider some of them equivalent of social capital by Almond and Verba. The results show that, trust each other is the main condition for the formation of secondary relationships that in turn affect the effective partnership. Banfield in a study in Italy found that the mutual trust among people is very low due to low participation as a result of low trust. This trust is due to long poverty and foreign domination. Jacob and Felt (2002) conducted a study on social capital and political participation, in which the impact of social capital on political participation of minority groups in Brussels has been measured. In this research, the Robert Putnam's theory has been used and the social capital in the narrower sense as a presence on social networks through membership in an association or collective life is used. The results show that Turkish people had more good relations and participation in voluntary associations than Moroccans. They concluded that the massiveness of company is linked with voluntary associations with political participation. Greely has used the concept of social capital (trust) of Coleman (1998) to explain the impact of religious structures on the type of community involvement (voluntary phenomenon). Jacquelines has evaluated the relationship between social and religious commitment with the phenomenon of participation and volunteering among Americans and Africans. The results showed that church commitment has a direct relationship with volunteering and membership of a social organization and men with a social capital higher than the church commitment spend more 
time doing volunteer works. Thus, there is a direct relationship between age, education, and social participation.

In a research conducted by Salarzadeh and Mahjoubi entitled comparison of the social capital and economic status in the academic success of students in Urmia, education is the most important institution in society that has the task of initial training of specialized personnel. If any factor could be identified to enhance the efficiency of this important social institution, it would be an important step to improve the welfare of citizens. In another research by Kiani and Mirzapour entitled spatial-locational differential analysis of urban and rural areas in social capital aspects (case study: the city of Khorramabad), Social capital is one of the factors affecting various aspects of human life, which has a strong influence on the basis of scientific and administrative development in rural and urban areas. The amount varies depending on the area. The results indicate that there is a huge gap between urban and rural areas in terms of social capital, in different aspects e.g. public trust in Khorramabad. The unofficial participation rate in rural areas is higher than the city in Khorramabad. Abdullahi and Mousavi in their research entitled social capital in Iran, the current situation, future prospects, and the possibility of the transition, concluded the low levels of social capital, prevail over any old and new negative role in preventing the realization of social cohesion at the national level. Strengthening of civil institutions, amending insights and individuals' practices is necessary to strengthen new social capital, especially in community relations and its positive consequences by improving the social environment of individual and collective actors.

\section{Research Methodology}

The research is applied and it follows a descriptive-analytic method. Documentation, library, and surveying (questionnaire) evaluations were used to collect the required data. The number of questions in this survey was designed based on four indicators of social capital, which were answered randomly by the citizens to collect data. One sample T- test was used to calculate the test. Thus, the average of indicators to calculate the satisfaction rate in each of the indicators is identified with this number. The statistical population in this research is 575,116 people residing in Zahedan in 2011. Random sampling method is used in this study to choose the sample size. The sample size is calculated using Cochran formula below. 383 samples have been determined based on Cochran formula and with a confidence level of $0.95 \%$ and the error level of $0.5 \%$. Finally, 385 people were selected to achieve perfect results. 


\section{The study area}

Zahedan is the capital of Sistan and Baluchestan as the largest province in the country. Zahedan is limited to Sistan from the north, Kerman from the west, Pakistan from the east and Khash city from the south (Ebrahimzadeh et al., 2004: 129). The legal area of Zahedan is 6413 of which, about 20 percent i.e. 1325 hectares are old texture back more than 30 years. The south and southwest of the city are tall while its height is reduced by moving to the north. The city is linked by many communication lines to different locations. Nosrat Abad and Bam road, Zabul and Hormak - Mashhad road, Khash - Iranshahr road, Mirjaveh and other secondary roads, especially railways to Mirjaveh are some of them. Zahedan is located at the end of Mashhad-Zahedan, Bam-Zahedan road, 83Kmaway from the shared border of Iran and Pakistan.

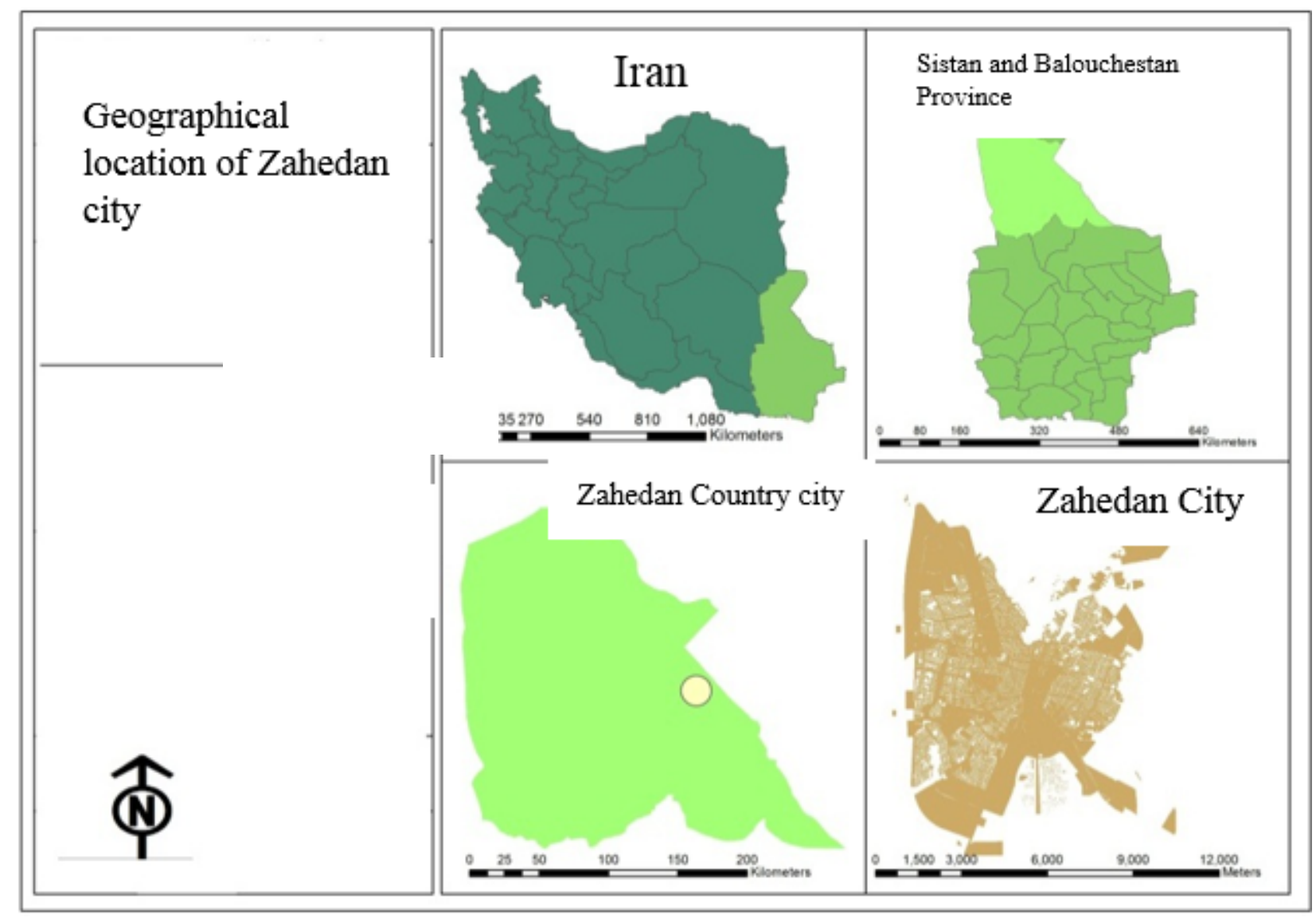

Figure 1: Geographical location of Zahedan 


\section{Theoretical Foundations}

\section{Definitions and theoretical approaches to social capital}

Social capital, which is a tangible form of an informal norm and causes collaboration between two or more individuals (Fukuyama, 2005), has a long history of mental and social sciences (Barghamadi, 2008: 267). This term was first raised by Hanyfan and then, it was seriously scrutinized in 1960 by John Jacobs in the influential book "The Life and Death in large American cities" (Hajipour, 43: 2006). The concept attracted the attention of academic circles in the 1990s (Abdullah and Mousavi, 119, 2007) and dramatically welcomed by the public so that the World Bank used this concept very much at different levels from local to national policy-making, even in some international organizations (Tavakoli and Tajbakhsh, 2008: 144). Social capital is a sociological concept, which is used in business, economics, humanities and public health to refer to communication within and between groups. Although there are various definitions for this concept, but social capital is considered as a type of "cure all problems" in the modern society (Sarookhani, 1991: 685). The first person who provided a careful and regular analysis of social capital is Pierre Bourdieu who defines social capital as "Social capital is the result of the accumulation of potential or actual resources related to possession of a durable network of more or less institutionalized relationships between individuals concerned with membership in a group" (Bourdieu, 198: 248). Social capital, according to Berem and Ron is a collective sense based on the behavior and attitude of the individual's talents. Accordingly, there are various institutions such as social institutions and voluntary organizations, family, religion and cultural patterns, which play role in shaping the habits and values generating social capital (Berem and Ron, 1997: 1000). In general, social capital has become the slogan of political, sociology, and economics science. It is a concept whose life backs to 18th Century and before it that recently is raised again in discussions of civil society (Rezaei, Naji, 2015). If we say, the civil society explains non-governmental organizations arrangement in governance. Thus, civil society explains the basic social relations through which institutional arrangements are emerged. With respect to any issue without examining the perspective of every theorists of social capital, different definitions are given for social capital:

- The interrelationship network between factors within the economy; (Barr, 2000: 539)

- Authority relations, trust relations, and allocation of created rights norms; (Coleman, 1998: 300).

- Informal norms that promote the growth of collaboration between two or more individuals (Fukuyama, 2000: 3). 
- Social organization forms such as networks, norms, and trust that facilitate coordination and cooperation for mutual benefit (Putnam, 2001: 67).

\section{Measuring social capital}

It must be said that the concept of social science is faced with great difficulties. Hence, Richard Feynman won the Nobel Prize in physics, has stated that the social sciences problems are more difficult than physics (Feynman, 1988). A part of this difficulty is due to the problems related to measurement. Concepts such as social capital include structures, which are inherently abstract and require subjective interpretations to be operational measures. Therefore, social capital as a complex concept cannot be measured with a single gauge or a number. According to Levi-Strauss, social capital is a concept at the time i.e. an ongoing process, not a fixed or static element. Thus, evaluating this concept should be over time not static at a particular moment. However, there is an agreement in the field of social capital and determining the shapes and dimensions and there is differing viewpoints in its operational definition (Paxton, 1999).

\section{Important aspects of social capital (knowledge, trust, participation, and social cohesion)}

Social capital has four important aspects of knowledge, trust, participation, and social cohesion that will be explained below.

\section{Knowledge:}

The initial precondition for social participation is "knowledge". Knowledge is a cognitive variable belongs to the people. Where people are not aware of the nature of social issues, or they do not know about available tools, the social participation opportunities and the strong sense and social storage will be lower. In fact, social capital can be achieved through action based on knowledge and mutual understanding. It is the result of the never-ending effort that are done to institutionalize the values to produce and reproduce meaningful and lasting relationships that supports material or spiritual benefits for the groups (www.isa.org.ir). The knowledge of community issues, having knowledge of the living environment, having information from the needs and gaps in living conditions and the individual and collective rights and responsibilities of people living in the neighborhood and the responsibility of government agencies against these deficiencies and needs can increase a person's knowledge and strengthen the social capital. Knowledge can be created or strengthened primarily through creating the spirit of knowledge in the individual and second, raising knowledge through education rights and responsibilities of people. Therefore, people with knowledge of their rights and responsibilities towards the society and living environment can behave correctly in order to improve the neighborhood (Tajbakhsh, 2005). 


\section{Trust}

Investigating the existing literature on the lack of a precise definition of the meaning of the word trust (Bhattacharya and Devinnery, 1998: 459). Trust is defined in the Oxford English Dictionary as follows:

- Ensure or reliance on some of the features or characteristics of a person or organization;

- Accept or give credit to a person or organization without review and receive evidence;

- Believe or rely on the integrity of an individual or organization;

- Reliable expectations of an individual or organization;

- Honesty, integrity, and loyalty (Alvani, Danaeefard, 2001: 7).

It should be said that in the definitions of trust, some expectations or beliefs commonly cited that people like and expect others to show in a predictable way (Luhman, 1979), not merely for self-interest. In other words, we rely on others to consider our interests. If these people are merely profit-driven, this will not form for them. Thus, if the trusted person only wants the personal interest, trust does not mean (Alvani, Danaeefard, 2001: 7). According to March and Olsen, the central idea of trust is that it is based on a kind of expectation (March and Olsen, 2010: 27). When people can achieve success by working in a local community that not only have prior direct and indirect knowledge of each other, but also have trust to each other and know that if they trust they would not be deceived and finally, they will benefit from its benefits. Coleman (1998) and Putnam (2001) argue that trust is one of the main keys of the social capital.

\section{Participation}

The word participation means involvement and gathering for a special purpose. It has been a lot of discussion about the literal meaning, but in general, its main essence is involvement, activity, and influence (Alavitabar, 2000: 15). Public participation means voluntary activity in the development process (Ebrahimzadeh, 1998: 2). Public participation in the development process is such a valid that development is considered as participation (Ebrahimzadeh, 1998: 1). Participation means contribution in something and taking the advantages or joining to a group and cooperating with them. Therefore, there is a difference between participation as stance and participation as an act from the sociological perspective. Participation in the second sense means belonging to a particular group and contributing to its existence, which intends carried out social activities (Saeedi Rezvani and Kazemina, 2001: 32,33).

In brief, public participation is the basic process, in which people wisely and with knowledge, determination and willingness accept responsibility in groups and try to satisfy the spiritual, mental, individual and collective needs and achieve the predetermined objectives based on 
actual prioritized needs considering features and limitations to identify the individual and collective identities in society. If we consider the scope of participation in the city as well as a kind of process based programming with the prospective framework and involve factors such as social justice, law, sustainable development, etc.; we will have a participatory planning (Biero, 1991).

\section{Social cohesion}

Social cohesion means that groups maintain their unity and comply with the unifying elements. Solidarity and cohesion is the sense of responsibility among some people or groups who have the knowledge and determination and a moral sense of duty or obligation, which imply a positive sense to show the interdependence of functions and components. In the sociological viewpoint, solidarity is a phenomenon, in which a group or society are dependent and mutually need each other. This does not require knowledge rejection and moral disapproval based on reciprocity and responsibility, but it is an invitation to meet and learn the values and sense of obligation (Abdollahi, Mousavi, 2007).

\section{Research findings}

In order to evaluate the contribution of social capital in Zahedan, the four indicators of participation, knowledge, trust, and social cohesion were used. For this purpose, one sample T- test was used. The average of the indicators to calculate the amount of satisfaction in each of the indicators is identified with this number. The average value is three. In this case, the upper and lower limit values are used. If upper and lower limit values were negative, the average will be lower than the observed value and if they were positive, the average will be higher than the observed value. Thus, first, each of the indicators is evaluated. In one sample T- test, $\mathrm{H}_{0}$ hypothesis indicates the equality of stability with number three (average) and $\mathrm{H}_{1}$ hypothesis indicates the lack of equality of stability with the average.

\section{Knowledge}

Knowledge, especially in the modern world plays a tremendous role in human life. Today, knowledge and information are a massive capital in the social developments and they grow increasingly in surface and depth so that knowledge is one of the most important factors to achieve social capital. Social knowledge is a set of thoughts, ideas, and sensitivity to life and considering what is in the broadest sense including political or social (Firoozabadi, 2005: 28). For this purpose, four indicators are intended as follows: 
Table 1: One sample T-test results for each of the components of knowledge

\begin{tabular}{|c|c|c|c|c|c|c|c|}
\hline \multirow{2}{*}{ No. } & \multirow{2}{*}{ Variable } & \multirow{2}{*}{ Average } & \multirow{2}{*}{$\begin{array}{c}\mathrm{T} \\
\text { statistic }\end{array}$} & \multirow{2}{*}{$\begin{array}{l}\text { Significance } \\
\text { level (sig) }\end{array}$} & \multirow{2}{*}{$\begin{array}{c}\text { Mean } \\
\text { difference }\end{array}$} & \multicolumn{2}{|c|}{$\begin{array}{l}\text { 95\% confidence } \\
\text { interval difference }\end{array}$} \\
\hline & & & & & & $\begin{array}{l}\text { Lower } \\
\text { bound }\end{array}$ & $\begin{array}{l}\text { upper } \\
\text { bound }\end{array}$ \\
\hline 1 & $\begin{array}{l}\text { Knowledge of their } \\
\text { chosen profession }\end{array}$ & 2.16 & -20.564 & 0.000 & -0.843 & -0.92 & -0.76 \\
\hline 2 & $\begin{array}{l}\text { Knowledge of } \\
\text { candidates }\end{array}$ & 2.59 & -9.656 & 0.000 & -0.414 & -0.50 & -0.33 \\
\hline 3 & $\begin{array}{l}\text { The daily reading } \\
\text { books and newspapers }\end{array}$ & 1.99 & -20.617 & 0.000 & -1.014 & -1.11 & -0.92 \\
\hline 4 & $\begin{array}{l}\text { Awareness of the } \\
\text { issues of the day }\end{array}$ & 2.11 & 17.866 & 0.000 & -0.886 & -0.98 & -0.79 \\
\hline
\end{tabular}

Table 2: Results of one sample T-test for knowledge indicator

\begin{tabular}{|c|c|c|c|c|c|c|}
\hline Variable & number & Average & $\mathrm{df}$ & $\mathrm{t}$ & $\begin{array}{c}\text { Significance } \\
\text { level (sig) }\end{array}$ & $\begin{array}{c}\text { Mean } \\
\text { difference }\end{array}$ \\
\hline knowledge & 385 & 1.439 & 384 & -11.369 & 0.000 & -1.560 \\
\hline
\end{tabular}

According to the obtained statistics from the test, average, and the confidence level of 95\%, and the significance level (Sig 0.000), which shows a values lower than alpha 0.05. The negative upper and lower bound shows that social capital is inadequate in knowledge and it is not satisfied by citizens.

\section{Participation}

This indicator is widely accepted as one of the basic aspects of social capital. Amartya Sen knows it as the ability of people to change the reality through social changes (Pourmohammadi et al., 2011: 43). The purpose of participation is the power of effectiveness on decisions and contribution of people in the power (Ebrahimzadeh and Asadi, 2012: 17). Social participation is a social, public, integrated, multiplied, multi-dimensional, and multicultural process, which aims to bring all people to play a role in all stages of development 
(Gaotri, 1986: 37). To assess this indicator, 5 criteria of business and financial participation in relation to the affairs and needs of the neighborhood with the municipality, participation in the municipal elections, participation in public and non-governmental associations, participation in public affairs related to neighborhood, participation in public works were included in the questionnaire.

Table 3: One-sample T test results for each component of partnership

\begin{tabular}{|c|c|c|c|c|c|c|c|}
\hline \multirow{2}{*}{$\dot{z}$} & \multirow[b]{2}{*}{ Variable } & \multirow{2}{*}{ Average } & \multirow{2}{*}{$\begin{array}{c}\mathrm{T} \\
\text { statistic }\end{array}$} & \multirow{2}{*}{$\begin{array}{l}\text { Significance } \\
\text { level (sig) }\end{array}$} & \multirow{2}{*}{$\begin{array}{c}\text { Mean } \\
\text { difference }\end{array}$} & \multicolumn{2}{|c|}{$\begin{array}{l}\text { 95\% confidence } \\
\text { interval difference }\end{array}$} \\
\hline & & & & & & $\begin{array}{l}\text { Lower } \\
\text { bound }\end{array}$ & $\begin{array}{l}\text { upper } \\
\text { bound }\end{array}$ \\
\hline 1 & $\begin{array}{l}\text { business and financial } \\
\text { participation in relation to } \\
\text { the affairs and needs of } \\
\text { neighborhood with the } \\
\text { municipality }\end{array}$ & 1.94 & -44.619 & 0.000 & -1.06 & -1.16 & - \\
\hline 2 & $\begin{array}{l}\text { participation in the } \\
\text { municipal elections }\end{array}$ & 1.88 & -49.859 & 0.000 & $-1 / 12$ & -1.23 & -1.01 \\
\hline 3 & $\begin{array}{l}\text { participation in public and } \\
\text { non-governmental } \\
\text { associations }\end{array}$ & 1.81 & -64.975 & 0.000 & -1.19 & -1.30 & -1.1 \\
\hline 4 & $\begin{array}{l}\text { participation in public affairs } \\
\text { related to neighborhood }\end{array}$ & 2.19 & -43.922 & 0.000 & -0.81 & -1.90 & -1.71 \\
\hline 5 & participation in public works & 2.93 & -34.723 & 0.003 & -0.07 & -0.18 & -0.01 \\
\hline
\end{tabular}

Table 4: Results of one sample T-test for participation

\begin{tabular}{|c|c|c|c|c|c|}
\hline Variable & Average & $\mathrm{df}$ & $\mathrm{t}$ & Mean difference & $\begin{array}{c}\text { Significance level } \\
\text { (sig) }\end{array}$ \\
\hline participation & 2.53 & 384 & -10.675 & -0.528 & 0.001 \\
\hline
\end{tabular}

As can be seen in the above table, p-value is less than 0.05. Thus, the null hypothesis of equality of average with number 3 will not be accepted. Given that the sig value was 0.001 , it 
can be concluded that citizen participation indicator as one of the important criteria of social capital, was inappropriate in terms of the collective agreement.

\section{Trust}

Trust is considered as one of the most important elements of social capital and the requirements of existing in any society, which seems necessary to solve social problems. Thus, it causes psychological safety and security. Trust is the sense of social relations and it has a direct relationship with social relations. Higher level of social trust increases the intensity, diversity, and sustainability in social relations (Tajbakhsh, 2005). Six criteria of trust in government employees, trust in the municipality of the city and district, trust in the City Council, trust in fellow citizens, trust in friends and acquaintances, and trust in relatives were considered to measure the trust indicator.

Table 5: one sample T-test results for each component of trust indicator

\begin{tabular}{|c|c|c|c|c|c|c|c|}
\hline \multirow[t]{2}{*}{$\dot{z}$} & \multirow{2}{*}{ Variable } & \multirow[t]{2}{*}{ Average } & \multirow[t]{2}{*}{ T statistic } & \multirow{2}{*}{$\begin{array}{c}\text { Signific } \\
\text { ance } \\
\text { level } \\
\text { (sig) }\end{array}$} & \multirow[t]{2}{*}{$\begin{array}{c}\text { Mean } \\
\text { difference }\end{array}$} & \multicolumn{2}{|c|}{$\begin{array}{c}95 \% \\
\text { confidence } \\
\text { interval } \\
\text { difference }\end{array}$} \\
\hline & & & & & & $\begin{array}{l}\text { Lower } \\
\text { bound }\end{array}$ & $\begin{array}{l}\text { upper } \\
\text { bound }\end{array}$ \\
\hline 1 & trust in government employees & 1.14 & -79.075 & 0.000 & -1.862 & -1.91 & -1.82 \\
\hline 2 & $\begin{array}{l}\text { trust in municipality of the } \\
\text { city and district }\end{array}$ & 1.07 & -103.44 & 0.000 & -1.926 & -1.96 & -1.89 \\
\hline 3 & trust in the City Council & 1.13 & -83.039 & 0.000 & -1.867 & -1.91 & -1.82 \\
\hline 4 & trust in fellow citizens & 2.03 & -26.658 & 0.000 & -0.974 & -1.05 & -0.90 \\
\hline 5 & $\begin{array}{l}\text { trust in friends and } \\
\text { acquaintances }\end{array}$ & 2.52 & -9.118 & 0.000 & -0.478 & -0.58 & -0.38 \\
\hline 6 & trust in relatives & 1.72 & -39.402 & 0.000 & -1.279 & -1.34 & -1.21 \\
\hline
\end{tabular}


Table 6: Results of one sample T-test for trust

\begin{tabular}{|l|c|c|c|c|c|}
\hline \multicolumn{1}{|c|}{ Variable } & Average & $\mathrm{df}$ & $\mathrm{t}$ & $\begin{array}{c}\text { Mean } \\
\text { difference }\end{array}$ & $\begin{array}{c}\text { Significance level } \\
\text { (sig) }\end{array}$ \\
\hline trust & 1.39 & 384 & -37.392 & -1.0606 & 0.002 \\
\hline
\end{tabular}

The results of Tables 5 and 6 show that given the significance level (0.002), which is smaller than the error rate (0.05), the satisfaction of Zahedan citizens with trust is less than average and undesirable.

\section{Social cohesion}

Social cohesion implies a collective agreement among members of a society. In other words, cohesion refers to the amount and pattern of mutual relationship between the actors, groups, and subcultures (Karkonan, 2009: 217). In order to assess this indicator in Zahedan, the 4 questions including gatherings and meetings to solve the problems in the neighborhood, cooperation to help the needy in the neighborhood, cooperation and participation in ceremonies and mourning, and warm and cordial relations with neighbors were used.

Table 7: one sample T-test results for each of the components of Social cohesion

\begin{tabular}{|c|c|c|c|c|c|c|c|}
\hline \multirow{2}{*}{$\dot{z}$} & \multirow[b]{2}{*}{ Variable } & \multirow{2}{*}{$\begin{array}{l}\text { Averag } \\
\text { e }\end{array}$} & \multirow{2}{*}{$\begin{array}{c}\mathrm{T} \\
\text { statistic }\end{array}$} & \multirow{2}{*}{$\begin{array}{c}\text { Signific } \\
\text { ance } \\
\text { level } \\
\text { (sig) }\end{array}$} & \multirow{2}{*}{$\begin{array}{c}\text { Mean } \\
\text { differenc } \\
\text { e }\end{array}$} & \multicolumn{2}{|c|}{$\begin{array}{l}\text { 95\% confidence } \\
\text { interval difference }\end{array}$} \\
\hline & & & & & & $\begin{array}{l}\text { Lower } \\
\text { bound }\end{array}$ & $\begin{array}{l}\text { upper } \\
\text { bound }\end{array}$ \\
\hline 1 & $\begin{array}{c}\text { gatherings and meetings to } \\
\text { solve the problems in the } \\
\text { neighborhood }\end{array}$ & 1.15 & -80.146 & 0.000 & -1.85 & -1.90 & -1.81 \\
\hline 2 & $\begin{array}{l}\text { cooperation to help the needy } \\
\text { in the neighborhood }\end{array}$ & 1.55 & -35.122 & 0.000 & -1.45 & -1.53 & -1.37 \\
\hline 3 & $\begin{array}{l}\text { cooperation and participation } \\
\text { in ceremonies and mourning }\end{array}$ & 3.18 & 4.040 & 0.000 & 0.184 & 0.09 & 0.27 \\
\hline 4 & $\begin{array}{c}\text { warm and cordial relations } \\
\text { with neighbors }\end{array}$ & 1.55 & -35.092 & 0.000 & -1.44 & -1.53 & -1.36 \\
\hline
\end{tabular}


Table 8: Results of one sample T test for social cohesion

\begin{tabular}{|l|c|c|c|c|c|}
\hline \multicolumn{1}{|c|}{ Variable } & Average & $\mathrm{df}$ & $\mathrm{t}$ & $\begin{array}{c}\text { Mean } \\
\text { difference }\end{array}$ & $\begin{array}{c}\text { Significance level } \\
\text { (sig) }\end{array}$ \\
\hline $\begin{array}{l}\text { social } \\
\text { cohesion }\end{array}$ & 1.86 & 384 & -47.043 & 0.000 & -1.14 \\
\hline
\end{tabular}

The four criteria as outlined in the above table were raised to measure the social capital. As can be seen in the above table, p-value is less than 0.05 . Thus, the null hypothesis of equality of average with number 3 will not be accepted. The lower amount of the average than the tested value shows that Zahedan citizens have complained about the social cohesion. They only satisfied with the third case i.e. cooperation and participation in ceremonies and mourning.

\section{Conclusion}

Despite the problems that most Third World cities, including Iran, are involved with it, it can be concluded that these problems arose from the third world, especially in Iran, planned or unplanned from the consequences of rapid urbanization and massive rural urban migration, macro-oriented approaches in planning and lack of attention to people's wishes and opinions. Attention to the wishes and views of the people and applying planning methods from down to up, which are mostly emphasized grassroots groups and informal, parties, organizations, civil society, and solve some of these problems private sector. The majority of these samples are shaped in the form of social capital. It should be said that the importance and necessity of social capital in urban functions have raised the plan of assessing the social capital and its most important aspects i.e. participation, knowledge, trust, and social cohesion in the city of Zahedan, which were used in this study. Findings showed that the participation indicator has an average of 2.53 and a mean difference of 0.528 (average of response equality). Given that the significant level is less than 0.05 , thus, they do not have the adequate participation in matters related to city and social capital in this indicator is not favorable. Regarding the indicator of knowledge, the calculated average is less than 0.05 . Therefore, citizens do not have enough knowledge at 95\% confidence level. Given that, the public participation in determining the urban goals and decision-making is very low. This has decreased their knowledge about the made decisions related to urban affairs. The test results of trust (sig=0.000) shows that social capital has not received an acceptable score on the knowledge criteria. Regarding the indicator of social cohesion, the test results (sig=0.000) show that social cohesion has not received an acceptable score from the citizens in most of the criteria 
and they only had a good performance in cooperation and participation in the ceremonies and mourning. According to the analysis of social capital criteria, the performance of all criteria in the city of Zahedan was undesirable.

\section{Recommendations:}

- Providing the proper context and framework for citizen participation in informal groups and organizations.

- Providing the opportunities for sustainable social structure development to maintain the social capital (This is possible by encouraging and providing various facilities).

- Accurate information about urban issues to raise the people's knowledge and creating motivate to raise a sense of cooperation.

- Promoting the culture of citizenship through training

- Formation of public supervision in the social municipal institutions

- Continuous training and culturalization in the field of supervision process to citizens according to their performance in the social municipal institutions

- Providing the opportunities for more interaction between citizens and exchanging their minds through cultural forums, etc.

- Developing policies and implementing varied programs for urban areas according to their prevailing culture

- Careful data analysis and needs assessment in the planning of neighborhoods and urban areas.

\section{References}

Abdollahi, Mohammad \& Mirtaher, Mousavi (2007). Social Capital in Iran; The Current Situation, Future Prospects and the Possibility of Transition, Journal of Social Welfare, Vol. 6, Issue 25, 2007.

Alavitabar, Alireza (2000). The Pattern of Citizen Participation in City Affairs (Global Experiences and Iran). The Municipalities.

Alizadeh, Hadi; Morteza, Nemati, \& Rezaei Jafari, Kamran (2015). Analysis of the Good Urban Governance Using Fuzzy Hierarchical Analysis, Urban and Regional Studies and Research. Sixth year, No. 24. 
Alvani, Seyed Mahdi \& Danaeifard, Hassan (2001). Governmental Administration and Public Trust, Knowledge of Management, No. 55.

Barghamadi, Hadi (2008). Effects of Diaspora Neighborhood Destruction on the Social Capital of Khak Sefid Neighborhood. Journal of Social Welfare. No. 28, the seventh year, Tehran University of Rehabilitation and Welfare.

Biero, Allen (1991). Social Sciences Culture, Translated by Baqer Sarookhani, Tehran: Keyhan Publications.

Coleman, James (1998). Foundations of Social Theory. Translated by Sabouri. Tehran: Ney Publications.

Ebrahimzadeh, Issa \& Asadi, Morteza (2012). Analysis and Evaluation of the Implementation of Urban Good Governance in Iran (Case Study: Kashmar). geography and urban-regional planning, No. 6, pp. 30-17.

Ebrahimzadeh, Issa (1998). Participative Management of Councils and Rural Management System in Iran, Journal of Humanities and Social Sciences Research Institute (SID). publishing (SID). The second issue.

Ebrahimzadeh, Issa; Barimani, Faramarz \& Nasiri, Yusef (2004). Suburbanization and urban anomalies and its modification strategies, Journal of Geography and Development Sistan and Baluchestan University, Second year, No. 3.

Firouzabadi, Seyed Ahmad (2005). Social Capital and Factors Affecting its Formation in Tehran. Faculty of Social Sciences of Tehran University PhD dissertation.

Fukuyama, Francis (2000). End of the Order, Social Capital and Maintain it. Translated by Gholam Abbas Tavasoli, Tehran: Jamea Iranian Publications.

Fukuyama, Francis (2005). Civil Society and Social Capital, Social Capital: Trust, Democracy and Development (Collected by Kian Tajbakhsh), Tehran: Shirazeh publication.

Hajipour, Khalil (2006). Neighborhood Planning - Effective Approach in The Development of Sustainable Urban Management, College of Fine Arts, Issue 26, Summer, Tehran University.

Karkonan, Mohsen (2009). Proceedings of the National Conference on Culture and Development in the Central Region of Iran.

Latifi, Gholareza \& Azimi, Mitra (2010). Social Capital and its Role in Planning and Urban Management, Specialized Monthly Notification, Review Book, No. 32, fourteenth year.

MehdiZadeh, Javad (2006). Strategic Planning of Urban Development, Ministry of Housing and Urban Development. 
PourMohammadi, Mohammad Reza; Hosseinzadeh, Dalir \& Karim Piri, Issa (2011). An Analysis of the Qualitative Change in the Social Capital of East Azarbaijan Province, Geographical Studies Arid Regions, The First Year, No. 3, pp. 19.

Putnam, Robert (2001). Democracy and Civil Traditions. Translated By Delafrouz, Muhammad Taqi. Tehran: Political Studies Office of the Interior Ministry.

Rezaei, Mohammad Reza \& Soudeh Negin, Naji (2015). Evaluating the Effective Strategies to Create Sustainable Communities with Participatory Approach (Case Study: Rahnamaei neighborhood of Yasouj). Research and Urban Planning Magazine, No. 20.

Saeedi Rezvani, Navid \& Kazemian, Gholamreza (2001). The Feasibility of Assigning New Tasks to the Municipalities, The First Edition (Theoretical Developments and Global Experiences). Municipalities Nations Publication.

Sarookhani, Baqer (1991). Introduction to the Encyclopedia of Social Sciences. Tehran: Kayhan publication.

Tajbakhsh, Kian (2005). Social Capital: Trust, Democracy and Development. Translated by Afshin Khakbaz and Hassan Pouyan, Tehran, Shirazeh Publications.

Tavakoli, Morteza \& Tajbakhsh, Kazem (2008). Analyzing the Social Capital of Sistan Border in Urban and Rural Areas, Journal of village and Development, Vol. 11, No. 2, pp. 143. 